\title{
PENGARUH KEPEMIMPINAN KEPALA SEKOLAH, KOMITMEN GURU, DISIPLIN KERJA GURU, DAN BUDAYA SEKOLAH TERHADAP KINERJA GURU SMK
}

\author{
Sidik Purwoko \\ SMA Bopkri I Yogyakarta \\ Jl. Wardhani No.2, Kotabaru, Gondokusuman, Yogyakarta, 55224, Indonesia \\ Corresponding Author. Email: sidik.purwoko@yahoo.com
}

\begin{abstract}
Abstrak
Penelitian ini bertujuan untuk mengetahui pengaruh Kepemimpinan Kepala Sekolah, Komitmen Guru, Disiplin Kerja Guru, dan Budaya Sekolah terhadap Kinerja Guru di SMK Negeri Kabupaten Sleman Yogyakarta. Penelitian ini merupakan penelitian korelasional dengan menggunakan pendekatan kuantitatif. Populasi dalam penelitian ini adalah seluruh guru di SMK Negeri yang berada di Kabupaten Sleman yang berjumlah 659 orang. Penentuan ukuran sampel dalam penelitian ini menggunakan teknik random sampling dengan mengacu table Krejcie dan Morgan. Uji coba instrumen menggunakan uji validitas dan uji reliabilitas Alpha Cronbach's. Teknik analisis data menggunakan uji prasyarat analisis yang meliputi uji normalitas, uji linieritas dan uji multikolinieritas. Pengujian hipotesis menggunakan analisis regresi dengan tingkat signifikansi ditentukan sebesar 5\%. Hasil penelitian menunjukkan bahwa: (1) terdapat pengaruh yang positif dan signifikan kepemimpinan kepala sekolah terhadap kinerja guru; (2) terdapat pengaruh yang positif dan signifikan komitmen guru terhadap kinerja guru; (3) terdapat pengaruh yang positif dan signifikan disiplin guru terhadap kinerja guru sebesar; (4) terdapat pengaruh yang positif dan signifikan budaya sekolah terhadap kinerja guru; (5) terdapat pengaruh yang positif dan signifikan kinerja kepemimpinan, komitmen guru, disiplin kerja guru dan budaya sekolah secara simultan terhadap kinerja guru.
\end{abstract}

Kata Kunci: kepemimpinan kepala sekolah, komitmen, disiplin kerja, budaya sekolah, kinerja guru

\section{THE INFLUENCE OF PRINCIPAL'S LEADERSHIP, TEACHER'S COMMITMENT, TEACHER'S WORK DISCIPLINE, AND SCHOOL CULTURE ON VOCATIONAL HIGH SCHOOL TEACHER'S PERFORMANCE}

\begin{abstract}
This research is aimed to know the influence of Principal's Leadership, Teacher's Commitment, Teacher's Work Discipline, and School Culture on Teacher's Performance in SMK Negeri in Sleman District. This research is a correlational design research that uses quantitative approach. Population in this research includes all teachers in SMK Negeri in Sleman District with a total of 659 persons. The sample measurement in this research applies random sampling technique by referring to Krejcie and Morgan table. The instrument trial uses Alpha Cronbach's validity test and reliability test. The method of analyzing the data uses analysis precondition test which covers normality test, linearity test and multicollinearity test. The hypothesis proposal uses regression analysis with significance level determined by 5\%. The results of this research indicate that: (1) there is a positive and significant influence on the principal's leadership on teacher performance; (2) there is a positive and significant influence on teacher's commitment to teacher performance; (3) there is a positive and significant influence from teacher discipline on teacher performance as much; (4) there is a positive and significant influence on school culture on teacher performance; (5) there is a positive and significant influence on leadership performance, teacher commitment, teacher work discipline and school culture simultaneously on teacher performance
\end{abstract}

Keywords: principal's leadership, commitment, teacher's work discipline, school culture, teacher's performance

Permalink/DOI: http://dx.doi.org/10.21831/amp.v6i2.8467 


\section{Pendahuluan}

Salah satu permasalahan pendidikan yang dihadapi oleh Bangsa Indonesia saat ini ialah rendahnya mutu pendidikan pada setiap jenjang dan satuan pendidikan, khususnya pendidikan dasar dan menengah. Direktur Pendidikan Badan Perencanaan dan Pembangunan Nasional (Bappenas) mengatakan bahwa berdasarkan data United Nations Development Program (UNDP) 2011, Indeks tingkat pendidikan Indonesia dinilai masih rendah yaitu $14,6 \%$, berbeda dengan Singapura dan Malaysia yang sudah mempunyai indeks tingkat pendidikan yang lebih baik yaitu 28\% dan 33\% (Syukro, 2013). Masih rendahnya kualitas pendidikan di Indonesia, akan melemahkan daya saing Indonesia dalam menghadapi masyarakat ekonomi Asean 2015.

Dalam Peraturan Pemerintah Republik Indonesia Nomor 74 Tahun 2008 tentang Guru (Presiden RI, 2008) disebutkan bahwa: "Guru adalah pendidik profesional dengan tugas utama mendidik, mengajar, membimbing, mengarahkan, melatih, menilai dan mengevaluasi peserta didik pada pendidikan anak usia dini jalur pendidikan formal, pendidikan dasar, dan pendidikan menengah". Guru adalah kunci utama dalam sistem pendidikan, hal lain, dalam dunia pendidikan khususnya sekolah tidak banyak berarti apabila fungsi dasar pembelajaran yaitu interaksi guru dengan peserta didik tidak berkualitas. Demikian pentingnya peran guru sehingga dapat disimpulkan bahwa peningkatan kualitas dan kinerja guru akan sangat berpengaruh terhadap kualitas/mutu pendidikan.

Kinerja guru merupakan elemen sinergis yang harus dikembangkan untuk menghasilkan tenaga pendidik yang profesional dan mampu melahirkan proses pendidikan yang relevan dengan tuntutan situasi, kondisi dan kebutuhan masyarakat pengguna lulusan. Dengan kinerja guru yang bermutu akan mampu menghasilkan sumber daya manusia yang berkualitas, sehingga dapat meningkatkan mutu sekolah.

Menurut pendapat Djohar (2006, p. 3), pendidikan di Indonesia menghadapi tantangan baik substansi maupun penyeleng- garaannya serta tantangan ke dalam maupun ke luar. Tantangan substansi lebih terarah kepada mutu pendidikan, sedangkan tantangan penyelenggaraan lebih terarah kepada praktisi pendidikan dan penyelenggaraan sistem pendidikan guru di Indonesia. Oleh sebab itu, kunci untuk meningkatkan daya saing Indonesia, dengan meningkatkan kualitas pendidikan dan melakukan terobosan terbaru dalam sektor pendidikan salah satunya dari sisi sumber daya manusianya.

Umtuk mewujudkan kinerja guru yang sesuai dengan harapan,maka dibutuhkan seorang kepala sekolah yang profesional. Hal ini sesuai dengan hasil penelitian yang dilakukan oleh Sudriyah \& Liana (2015, p. 3) yang menyatakan bahwa supervisi kepala sekolah berpengaruh positif dan signifikan terhadap kinerja guru. Oleh karena itu, kepala sekolah sebagai bagian dari sistem sekolah menduduki posisi strategis dalam mengarahkan dan mendukung aktivitas guru dalam pembelajaran siswa. Kepala sekolah sebagai pemimpin organisasi sekolah mempunyai peranan yang sangat penting dalam rangka meningkatkan kinerja guru. Peran kepemimpinan kepala sekolah sangat dibutuhkan untuk mendukung terciptanya kualitas kinerja guru yang profesional di sekolah. Kepala sekolah berperan sebagai seorang pemimpin yang memiliki visi ke masa depan yang jelas dan dapat mewujudkan serta mampu mendorong proses transformasi di sekolah.

Menurut pendapat Hasibuan \& Moedjiono (2006, p. 40) yang menyatakan bahwa salah satu faktor yang mempengaruhi kinerja guru dalam melaksanaan tugas mengajar yakni faktor perilaku guru. Faktor perilaku guru sangat menentukan proses keberhasilan belajar siswa diantaranya komitmen guru sebagai faktor intern dari perilaku guru. Komitmen guru sangat penting bagi sekolah dan memilik efek positif terhadap prestasi siswa di sekolah. Dengan demikian, komitmen seorang guru dapat mempengaruhi kinerja guru di sekolah dan secara langsung hal ini dapat meningkatkan prestasi belajar siswa di sekolah. 
Kinerja guru yang tinggi tidak dapat tercapai jika tidak disertai tidak adanya ketaatan peraturan-peraturan yang berlaku dalam melaksanakan pekerjaan. Hal ini sesuai dengan pendapat yang dikemukakan oleh Terry (1993, p. 43) bahwa disiplin kerja seorang guru dapat dilihat dari kepatuhan guru terhadap peraturan yang berlaku di sekolah. Dengan kata lain diperlukan adanya disiplin kerja dalam suatu pekerjaan merupakan kehendak dan kesediaan guru untuk memenuhi dan menaati peraturanperaturan yang berlaku baik yang terulis maupun tidak tertulis. Disiplin kerja merupakan sikap mental yang senantiasa untuk menaati segala peraturan dan ketentuan yang telah ditetapkan untuk tujuan tertentu. Dengan disiplin kerja yang baik akan lebih meningkatkan kinerja guru yang pada akhirnya akan dapat meningkatkan mutu pendidikan.

Berdasarkan pengamatan di beberapa sekolah yang menjadi obyek penelitian, disiplin kerja guru dalam melaksanakan tugasnya belum sepenuhnya dilakukan dengan baik. Masih tertang mengajarnya terlambat dan malas mengajar. Meskipun hanya sebagian kecil saja, tetapi hal ini tentu akan mempengaruhi dan mengganggu proses belajar mengajar di sekolah. Selain itu masih ada guru yang datang pada saat jam mengajar saja.

Budaya sekolah sering disebut dengan iklim kerja yang menggambarkan suasana hubungan kerja antara sesama guru, antara guru dengan kepala sekolah, antara guru dengan tenaga kependidikan lainnya serta antardinas merupakan wujud dari lingkungan yang kondusif. Menurut Hasanah (2008, p. 12), budaya sekolah dapat digambarkan melalui sikap saling mendukung (supportive), tingkat persahabatan (collegial), tingkat keintiman (intimate) serta kerja sama (cooperative). Kondisi yang terjadi atas keempat dimensi budaya sekolah tersebut berpotensi meningkatkan kinerja guru. Apabila budaya sekolah dapat dikembangkan maka efektivitas dan produktivitas sekolah akan meningkat dan peningkatan tersebut akan berdampak pada peningkatan kinerja.
Peningkatan kinerja sekolah sangat dipengaruhi oleh nilai-nilai budaya yang dikembangkan dalam sekolah tersebut, dimana nilai-nilai yang dikembangkan di sekolah, tentunya tidak dapat dilepaskan dari keberadaan sekolah itu sendiri sebagai organisasi pendidikan. Budaya sekolah terbentuk dari eratnya kegiatan akademik dan kesiswaan, kegiatan karya ilmiah yang beragam bagi guru, kegiatan silaturahmi keluarga besar sekolah, karyawisata, studi banding, dan diklat akan memacu guru untuk meningkatkan kinerjanya. Berdasarkan uraian di atas, dapat disimpulkan bahwa kinerja guru dipengaruhi oleh sinergisnya proses interaksi antara faktor-faktor yang mempengaruhi kinerja guru yakni kepemimpinan, komitmen guru, disiplin kerja guru dan budaya sekolah.

Komitmen guru dan disiplin kerja juga tampak masih kurang. Hal ini terlihat masih banyak guru yang datang terlambat dan jam belajar kosong karena guru sedang di luar sekolah. Selain itu budaya sekolah juga relatif masih kurang baik. Hal ini dapat ditunjukkan oleh minat baca guru yang masih rendah, minimnya guru dalam menulis bahan ajar sehingga wawasan wawasan untuk melakukan pembenahan kualitas bahan ajar dan pengayaan metode pendekatan praktis pada proses belajar mengajar di sekolah belum optimal. Budaya sekolah merupakan ciri khas, karakter atau watak, dan citra sekolah tersebut di masyarakat luas. Oleh karena itu budaya sekolah yang positif perlu diimplementasikan sehingga produktivitas sekolah akan meningkat dan peningkatan tersebut akan berdampak pada peningkatan mutu sekolah.

Berdasarkan uraian permasalahan di atas, maka dapat disimpulkan bahwa mutu sekolah SMK Negeri di Kabupaten Sleman menjadi sebuah tanggungjawab yang besar bagi guru untuk meningkatkan kinerjanya. Kinerja guru merupakan barometer kualitas layanan pendidikan di suatu penyelenggaraan pendidikan. Kepemimpinan kepala sekolah, komitmen guru, disiplin kerja guru dan budaya sekolah harus dapat mengupayakan peningkatan kinerja guru. Oleh karena itu, kepemimpinan kepala sekolah, 
komitmen guru, disiplin kerja guru dan budaya sekolah merupakan faktor yang berpengaruh dalam meningkatkan kinerja guru.

Berdasrakan uraian tersebut, penelitian ini bertujuan untuk mengetahui pengaruh Kepemimpinan Kepala Sekolah, Komitmen Guru, Disiplin Kerja Guru, dan Budaya Sekolah terhadap Kinerja Guru di SMK Negeri Kabupaten Sleman Yogyakarta

\section{Metode Penelitian}

Penelitian ini termasuk jenis penelitian korelasional yaitu suatu penelitian untuk mengetahui hubungan dan tingkat hubungan antara dua variabel atau lebih. Penelitian ini menggunakan pendekatan kuantitatif.

Penelitian dilaksanakan di SMK Negeri yang berada di kabupaten Sleman DIYyang meliputi: (1) SMKN 1 Cangkringan, (2) SMKN 1 Depok, (3) SMKN 2 Depok, (4) SMKN 1 Godean, (5) SMKN 2 Godean, (6) SMKN 1 Kalasan, (7) SMKN 1 Seyegan, dan (8) SMKN 1 Tempel. Penelitian dilaksanakan selama 3 bulan mulai bulan Januari sampai dengan bulan Maret 2015. Populasi dalam penelitian ini adalah seluruh guru di SMK Negeri yang berada di Kabupaten Sleman yang berjumlah 659 orang. Berikut data selengkapnya mengenai populasi dalam penelitian ini.

Teknik yang digunakan dalam menentukan sampel pada penelitian ini adalah dengan teknikrandom sampling, Variabel dalam penelitian ini meliputi empat variabel bebas, yaitu kepemimpinan kepala sekolah (X1), komitmen guru (X2), disiplin kerja guru (X3), dan budaya sekolah (X4) serta satu variabel terikat yaitu kinerja guru $(\mathrm{Y})$.

Pengumpulan data dalam penelitian ini menggunakan kuesioner/angket dan dokumentasi. Instrumen atau alat yang digunakan dalam penelitian ini berupa kuesioner/angket. Kuesioner yang digunakan untuk menyelidiki pendapat subjek mengenai suatu hal atau untuk mengungkapkan kepada responden menggunakan skala (rating scale).

Teknik pengumpulan data variabel kepemimpinan kepala sekolah (X1), komitmet guru (X2), disiplin kerja (X3), budaya
sekolah(X4), kinerja guru (Y) menggunakan angket tertutup (closed ended). Instrumen pengumpulan data pada tiap-tiap variabel diuraikan ke dalam indikator dan subindikator masing-masing.

Sebelum angket digunakan dengan sesungguhnya, terlebih dahulu dilakukan uji coba kepada responden untuk mengetahui tingkat validitas dan reliabilitas instrumen. Pengujian validitas dilakukan dengan validitas konstruk (construct validity). Uji realibilitas instrumen kepada 30 responden untuk variabel kinerja guru, kepemimpinan kepala sekolah, komitmen guru, disiplin kerja, dan budaya sekolah adalah sbb: nilai Alpha (Cronbach's) untuk variabel kinerja guru sebesar 0,926, variabel kepemimpinan kepala sekolah sebesar 0,936 , variabel komitmen guru sebesar 0,838 , variabel disiplin kerja sebesar 0,800 dan variabel budaya sekolah sebesar 0,838, karena nilai tersebut lebih dari 0,600 maka instrumen dalam penelitian ini dinyatakan reliabel.

Data yang diperoleh dari lapangan selanjutnya akan dianalisis menggunakan analisis statistik yang terdiri dari analisis deskriptif dan analisis inferensial. Penelitian ini menggunakan statistik parametrik, sehingga harus dilakukan uji prasyarat analisis. Uji prasyarat yang dilakukan meliputi: (1) Uji Formalities, (2) Uji Linieritas, (3) Uji Multikolinieritas, (4) Uji Autokorelasi dan (5) Uji Heterokedastisitas.

Pengujian hipotesis dalam penelitian ini yaitu: Hipotesis pertama, kedua, ketiga dan keempat diuji dengan regresi sederhana (hubungan satu variabel independen terhadap satu variabel dependen). Persamaan garis regresi sederhananya dapat dirumuskan sebagai berikut: $Y=a+b_{1} X_{1} ; Y=a+$ $\mathrm{b}_{2} \mathrm{X}_{2} ; \mathrm{Y}=\mathrm{a}+\mathrm{b}_{3} \mathrm{X}_{3}$; dan $\mathrm{Y}=\mathrm{a}+\mathrm{b}_{4} \mathrm{X}_{4}$ di mana $Y=$ kinerja guru $X_{1}=$ kepemimpinan; $X_{2}=$ komitmen guru; $X_{3}=$ disiplin kerja guru;dan $\mathrm{X}_{4}=$ budaya sekolah

Hipotesis kelima diuji dengan menggunakan regresiberganda(hubungan antara dua atau lebih variabel independen terhadap satu atau lebih variabel dependen). Analisis dilanjutkan dengan menghitung persamaan regresinya, untuk memprediksi seberapa tinggi nilai variabel dependen bila 
nilai variabel independen dimanipulasi. Persamaan garis regresi secara umum dirumuskan sebagai berikut: $Y=a+b_{1} X_{1}+$ $b_{2} X_{2}+b_{3} X_{3}+b_{4} X_{4}$ dengan keterangan rumus: $\mathrm{Y}=$ kinerja guru (variabel dependen); $\mathrm{X}_{1}=$ kepemimpinan kepala sekolah (variabel independen); $\mathrm{X}_{2}=$ komitmen guru (variabel independen); $X_{3}=$ disiplin kerja guru (variabel independen); $\mathrm{X}_{4}=$ budaya sekolah (variabel independen); $a=$ konstanta; $b_{1}, b_{2}$, $b_{3}, b_{4}=$ Koefisien.

Sedangkan untuk menguji signifikansi konstanta dan setiap variabel independen dibangun Hapotesis sebagai berikut:

Ho $=$ Koefisien Regresi Tidak Signifikan

$\mathrm{Ha}=$ Koefisien Regresi Signifikan

Pengambilan keputusan berdasarkan probabilitas, yaitu dengan cara melihat kolom signifikansi (Sig.) dan diperoleh hasil sebagai berikut:

Jika Sig. > 0,05 maka Ho diterima, Ha ditolak Jika Sig. < 0,05 maka Ho ditolak , Ha diterima

\section{Hasil Penelitian dan Pembahasan}

Deskripsi Hasil Penelitian

Jawaban kuesioner yang telah dikumpulkan kemudian dianalisis untuk mengetahui deskripsi kepemimpinan kepala sekolah, komitmen guru, disiplin kerja guru, budaya sekolah dan kinerja guru di SMK Kabupaten Sleman. Dalam hal ini analisis yang digunakan adalah analisis deskriptif. Data penilaian guru terhadap setiap variabel penelitian adalah sebagai berikut.

Variabel Kepemimpinan Kepala Sekolah

Data variabel kepemimpinankepala sekolah diperoleh melalui kuesioner variabel kepemimpinankepala sekolah dengan 30 butir pernyataan dan jumlah responden 242 guru. Berdasarkan data kepemimpinan kepala sekolah yang diolah maka diperoleh skor tertinggi sebesar 120,00 dan skor terendah sebesar 55.00. Hasil analisis menunjukkan rerata (mean) sebesar 101.76, median 103,00 , modus 120.00 , varian sebesar 148,58 , range sebesar 65,00 dan standar deviasi sebesar 12,18.

Selanjutnya jumlah kelas dapat dihitung dengan menggunakan rumus $1+3,3$ $\log \mathrm{n}$, dimana $\mathrm{n}$ adalah subjek penelitian. Dari perhitungan diketahui bahwa $n=242$ sehingga diperoleh banyak kelas $1+3,3 \log$ $242=8,8666$ dibulatkan menjadi 9 kelas interval. Rentang data dihitung dengan rumus nilai maksimal - nilai minimal, sehingga diperoleh rentang data sebesar 120.00 $55.00=65,00$. Dengan diketahui rentang data maka dapat diperoleh panjang kelas sebesar 7,2 . Tabel distribusi frekuensi variabel kepemimpinan kepala sekolah disajikan sebagaimana Tabel 1.

Tabel 1. Distribusi Frekuensi Variabel Kepemimpinan Kepala Sekolah

\begin{tabular}{clll}
\hline No. & Interval & F & Persentase \\
\hline 1 & $113,4-120,6$ & 45 & $18,60 \%$ \\
2 & $106,1-113,3$ & 47 & $19,42 \%$ \\
3 & $98,8-106$ & 60 & $24,79 \%$ \\
4 & $91,5-98,7$ & 39 & $16,12 \%$ \\
5 & $84,2-91,4$ & 35 & $14,46 \%$ \\
6 & $76,9-84,1$ & 9 & $3,72 \%$ \\
7 & $69.6-76,8$ & 6 & $2,48 \%$ \\
8 & $62,3-69,5$ & 0 & $0,00 \%$ \\
9 & $55-62.2$ & 1 & $0,41 \%$ \\
& Jumlah & 242 & $100,00 \%$ \\
\hline
\end{tabular}

(Sumber: Hasil olah data, 2015)

Kemudian penentuan kecenderungan variabel setelah nilai minimum ( $\mathrm{Xmin}$ ) dan nilai maksimum (Xmax) diketahui yaitu 30 dan 120, maka selanjutnya mencari nilai rata-rata ideal $(\mathrm{Mi})$ dengan rumus $\mathrm{Mi}=1 / 2$ (Xmax $+X \min )$, mencari standar deviasi ideal (SDi) dengan rumus Sdi $=1 / 6\left(X_{\max }-X_{\min }\right)$. Berdasarkan acuan norma di atas, meanideal variabel kepemimpinankepala sekolah adalah 75. Standar deviasi ideal adalah 15. Dari perhitungan di atas dapat dikategorikan dalam 3 kelas yaitu baik, cukup dan kurang. Berdasarkan perhitungan dapat dibuat tabel kategorisasi kecenderungan variabel kepemimpinan kepala sekolah sebagai berikut.

Tabel 2. Kecenderungan Variabel KepemimpinanKepala Sekolah

\begin{tabular}{ccccc}
\hline No & Skor & Frekuensi & Persentase & Kategori \\
\hline 1 & $\geq 90$ & 209 & 86,4 & Baik \\
2 & $60-89$ & 32 & 13,2 & Cukup \\
3 & $<60$ & 1 & 0,4 & Kurang \\
& Total & 242 & 100,0 & \\
\hline
\end{tabular}

(Sumber: Hasil olah data, 2015) 


\section{Variabel Komitmen Guru}

Data variabel komitmen guru diperoleh melalui kuesioner komitmen guru dengan 9 butir pernyataan dan jumlah responden 242 guru. Berdasarkan data komitmen guru yang diolah maka diperoleh skor tertinggi sebesar 36,00 dan skor terendah sebesar 17.00. Hasil analisis menunjukkan rerata (mean) sebesar 26,08; median 26,00; modus 27,00 , varian sebesar 12,76 , range sebesar 19,00 dan standar deviasi sebesar 3,57.

Kemudian jumlah kelas dapat dihitung dengan menggunakan rumus $1+3.3$ $\log \mathrm{n}$, dimana $\mathrm{n}$ adalah subjek penelitian. Dari perhitungan diketahui bahwa $n=242$ sehingga diperoleh banyak kelas $1+3.3 \mathrm{log}$ $242=8,8666$ dibulatkan menjadi 9 kelas interval. Rentang data dihitung dengan rumus nilai maksimal - nilai minimal, sehingga diperoleh rentang data sebesar 36,00 - 17,00 = 19,00. Dengan diketahui rentang data maka dapat diperoleh panjang kelas sebesar 2,111 dibulatkan menjadi 2,1. Berikut ini disajikan tabel distribusi frekuensi variabel komitmen guru.

Tabel 3. Distribusi Frekuensi Variabel Komitmen Guru

\begin{tabular}{llll}
\hline No. & Interval & F & Persentase \\
\hline 1 & $34,6-36,7$ & 2 & $0,83 \%$ \\
2 & $32,4-34,5$ & 9 & $3,72 \%$ \\
3 & $30,2-32,3$ & 15 & $6,20 \%$ \\
4 & $28,0-30,1$ & 50 & $20,66 \%$ \\
5 & $25,8-27,9$ & 60 & $24,79 \%$ \\
6 & $23,6-25,7$ & 52 & $21,49 \%$ \\
7 & $21,4-23,5$ & 36 & $14,88 \%$ \\
8 & $19,2-21,3$ & 6 & $2,48 \%$ \\
9 & $17,0-19,1$ & 12 & $4,96 \%$ \\
& Jumlah & 242 & $100,00 \%$ \\
\hline
\end{tabular}

(Sumber: Hasil olah data, 2015)

Penentuan kecenderungan variabel, setelah nilai minimum ( $\mathrm{Xmin})$ dan nilai maksimum (Xmax) diketahui yaitu 9 dan 36, maka selanjutnya mencari nilai rata-rata ideal (Mi) dengan rumus $\mathrm{Mi}=1 / 2\left(X_{\max }+\right.$ $X \mathrm{~min})$, mencari standar deviasi ideal (SDi) dengan rumus Sdi $=1 / 6\left(X_{\max }-X_{\min }\right)$. Berdasarkan acuan norma di atas, meanideal variabel komitmen guru adalah 22,5. Standar deviasi ideal adalah 4,5. Dari perhitungan di atas dapat dikategorikan dalam 3 kelas yaitu baik, cukup dan kurang.

Berdasarkan perhitungan tersebut dapat dibuat tabel distribusi kecenderungan, adapun distribusi kecenderungan variabel komitmen guru disajikan pada Tabel 4.

Tabel 4. Kategorisasi Variabel Komitmen Guru

\begin{tabular}{ccccc}
\hline No & Skor & Frekuensi & Persentase & Kategori \\
\hline 1 & $\geq 27$ & 110 & 45,5 & Baik \\
2 & $18-26$ & 130 & 53,7 & Cukup \\
3 & $<18$ & 2 & 0,8 & Kurang \\
& Total & 242 & 100,0 & \\
\hline
\end{tabular}

(Sumber: Hasil olah data, 2015)

Berdasarkan Tabel 4 tersebut kecenderungan komitmen guru pada kategori cukup sebanyak 130 guru $(53,7 \%)$. Selanjutnya pada kategori baik sebanyak 110 guru (45,5\%),dan pada kategori kurang sebanyak 2 guru $(0,8 \%)$. Dengan demikian kecenderungan komitmen guru dalam kategori cukup.

\section{Variabel Disiplin Kerja}

Data variabel disiplin kerja diperoleh melalui kuesioner disiplin kerja dengan 17 butir pernyataan dan jumlah responden 242 guru. Berdasarkan data maka diperoleh skor tertinggi sebesar 65,00 dan skor terendah sebesar 37,00. Hasil analisis menunjukkan rerata (mean) sebesar 49,58, median 49,00, modus 49,00, varians sebesar 41.34, range sebesar 28.00 dan standar deviasi sebesar 6,43 . Selanjutnya jumlah kelas dapat dihitung dengan menggunakan rumus $1+$ $3.3 \log n$, dimana $n$ adalah subjek penelitian. Dari perhitungan diketahui bahwa $n=242$ sehingga diperoleh banyak kelas $1+3,3 \log$ $2242=8,866$ dibulatkan menjadi 9 kelas interval. Rentang data dihitung dengan rumus nilai maksimal-nilai minimal, sehingga diperoleh rentang data sebesar $65-37=28$. Dengan diketahui rentang data maka dapat diperoleh panjang kelas sebesar 3.111 dibulatkan menjadi 3.1. Distribusi frekuensi variabel disiplin kerja disajikan pada Tabel 5. 
Tabel 5. Distribusi Frekuensi Variabel Disiplin Kerja

\begin{tabular}{llll}
\hline No. & \multicolumn{1}{c}{ Interval } & $\mathrm{F}$ & Persentase \\
\hline 1 & $62,6-65,7$ & 4 & $1,65 \%$ \\
2 & $59,4-62,5$ & 13 & $5,37 \%$ \\
3 & $56,2-59,3$ & 25 & $10,33 \%$ \\
4 & $53,0-56,1$ & 33 & $13,64 \%$ \\
5 & $49,8-52,9$ & 35 & $14,46 \%$ \\
6 & $46,6-49,7$ & 47 & $19,42 \%$ \\
7 & $43,4-46,5$ & 43 & $17,77 \%$ \\
8 & $40,2-43,3$ & 26 & $10,74 \%$ \\
9 & $37,0-40,1$ & 16 & $6,61 \%$ \\
& Jumlah & 242 & $100,00 \%$ \\
\hline
\end{tabular}

(Sumber: Hasil olah data, 2015)

Penentuan kecenderungan variabel, maka selanjutnya mencari nilai rata-rata ideal (Mi) dengan rumus $\mathrm{Mi}=1 / 2(\mathrm{Xmax}+$ $\mathrm{Xmin})$, mencari standar deviasi ideal (SDi) dengan rumus $S d i=1 / 6\left(X_{\max }-X_{\min }\right)$. Berdasarkan acuan norma di atas, mean variabel disiplin kerja adalah 42,50, dan standar deviasi ideal adalah 8,5. Dari perhitungan di atas dapat dikategorikan dalam 3 kelas yaitu baik, cukup dan kurang.

Berdasarkan perhitungan tersebut dapat dibuat tabel distribusi kecenderungan variabel disiplin kerja disajikan pada Tabel 6.

Tabel 6. Kategorisasi Variabel Disiplin Kerja

\begin{tabular}{ccccc}
\hline No & Skor & Frekuensi & Persentase & Kategori \\
\hline 1 & $\geq 51$ & 97 & 40,1 & Baik \\
2 & $34-50$ & 145 & 59,9 & Cukup \\
3 & $<34$ & 0 & 0 & Kurang \\
& & 242 & 100,0 & \\
\hline
\end{tabular}

(Sumber: Hasil olah data, 2015)

Tabel 6 menunjukkan bahwa kategorisasi disiplin kerja sebagian besar pada kategori cukup sebanyak 145 guru (59,9\%). Sisanya berada pada kategori baik sebanyak 97 guru $(40,1 \%)$ dan pada kategori kurang tidak ada. Dengan demikian dapat disimpulkan bahwa kecenderungan disiplin kerja guru di SMK Kabupaten Sleman pada kategori cukup.

\section{Variabel Budaya Sekolah}

Data variabel budaya sekolah diperoleh melalui budaya sekolah dengan 21 butir pernyataan dan jumlah responden 242 guru. Berdasarkan data budaya sekolah yang diolah maka diperoleh skor tertinggi sebesar 86,00 dan skor terendah sebesar 43,00. Hasil analisis menunjukkan rerata (mean) sebesar 61,92, median 62,00, modus 63,00 , varians sebesar 79.54 , range sebesar 43,00 dan standar deviasi sebesar 8,91.

Selanjutnya jumlah kelas dapat dihitung dengan menggunakan rumus $1+3,3$ $\log \mathrm{n}$, dimana $\mathrm{n}$ adalah subjek penelitian. Dari perhitungan diketahui bahwa $n=242$ sehingga diperoleh banyak kelas $1+3,3 \mathrm{log}$ $242=8,866$ dibulatkan menjadi 9 kelas interval. Rentang data dihitung dengan rumus nilai maksimal - nilai minimal, sehingga diperoleh rentang data sebesar $86-43=43$. Dengan diketahui rentang data maka dapat diperoleh panjang kelas sebesar 4.777 dibulatkan menjadi 4,8 .

Tabel 7. Distribusi Frekuensi Variabel Budaya Sekolah

\begin{tabular}{llll}
\hline \multicolumn{2}{l}{ No.Interval } & $\mathrm{F}$ & Persentase \\
\hline 1 & $82,2-87,0$ & 5 & $2,07 \%$ \\
2 & $77,3-82,1$ & 1 & $0,41 \%$ \\
3 & $72,4-77,2$ & 25 & $10,33 \%$ \\
4 & $67,5-72,3$ & 35 & $14,46 \%$ \\
5 & $62,6-67,4$ & 54 & $22,31 \%$ \\
6 & $57,7-62,5$ & 46 & $19,01 \%$ \\
7 & $52,8-57,6$ & 39 & $16,12 \%$ \\
8 & $47,9-52,7$ & 20 & $8,26 \%$ \\
9 & $43,0-47,8$ & 17 & $7,02 \%$ \\
& Jumlah & 242 & $100,00 \%$ \\
\hline
\end{tabular}

(Sumber: Hasil olah data, 2015)

Penentuan kecenderungan variabel, maka selanjutnya mencari nilai rata-rata ideal (Mi) dengan rumus $\mathrm{Mi}=1 / 2\left(\mathrm{X}_{\max }+\right.$ $X \mathrm{~min})$, mencari standar deviasi ideal (SDi) dengan rumus $\mathrm{Sdi}=1 / 6\left(X_{\max }-X_{\min }\right)$. Berdasarkan acuan norma di atas, mean variabel budaya sekolah adalah 52.5, dan standar deviasi ideal adalah 10,5. Dari perhitungan di atas dapat dikategorikan dalam 3 kelas yaitu baik, cukup dan kurang.

Berdasarkan perhitungan tersebut dapat dibuat tabel distribusi kecenderungan variabel budaya sekolah sebagaimana disajikan pada Tabel 8 . 
Tabel 8. Kategorisasi Variabel Budaya Sekolah

\begin{tabular}{ccccc}
\hline No & Skor & Frekuensi & Persentase & Kategori \\
\hline 1 & $\geq 63$ & 120 & 49,6 & Baik \\
2 & $42-62$ & 122 & 50,4 & Cukup \\
3 & $<42$ & 0 & 0 & Kurang \\
& & 242 & 100,0 & \\
\hline
\end{tabular}

(Sumber: Hasil olah data, 2015)

Tabel 8 menunjukkan bahwa kategorisasi disiplin kerja sebagian besar pada kategori baik sebanyak 120 guru $(49,6 \%)$. Sisanya berada pada kategori cukup sebanyak 122 guru (50,4\%) dan pada kategori kurang tidak ada. Dengan demikian dapat disimpulkan bahwa kecenderungan budaya sekolah di SMK Kabupaten Sleman pada kategori baik.

\section{Variabel Kinerja Guru}

Data variabel kinerja guru diperoleh melalui kinerja guru dengan 32 butir pernyataan dan jumlah responden 242 guru. Berdasarkan data kinerja guru yang diolah maka diperoleh skor tertinggi sebesar 128,00 dan skor terendah sebesar 77.00. Hasil analisis menunjukkan rerata (mean) sebesar 101,55, median 100,00, modus 96,00, varians sebesar 159,48 , range sebesar 51,00 dan standar deviasi sebesar 12,62. Rentang data dihitung dengan rumus nilai maksimal - nilai minimal, sehingga diperoleh rentang data sebesar $128-77=51$. Dengan diketahui rentang data maka dapat diperoleh panjang kelas sebesar 5.67 dibulatkan menjadi 5.7. Berikut adalah tabel distribusi frekuensi variabel kinerja guru:

Tabel 9. Distribusi Frekuensi Variabel Kinerja Guru

\begin{tabular}{llll}
\hline No. & Interval & F & Persentase \\
\hline 1 & $123,4-129,1$ & 6 & $2,48 \%$ \\
2 & $117,6-123,3$ & 23 & $9,50 \%$ \\
3 & $111,8-117,5$ & 31 & $12,81 \%$ \\
4 & $106,0-111,7$ & 41 & $16,94 \%$ \\
5 & $100,2-105,9$ & 19 & $7,85 \%$ \\
6 & $94,4-100,1$ & 46 & $19,01 \%$ \\
7 & $88,6-94,3$ & 34 & $14,05 \%$ \\
8 & $82,8-88,5$ & 24 & $9,92 \%$ \\
9 & $77,0-82,7$ & 18 & $7,44 \%$ \\
& Jumlah & 242 & $100,00 \%$ \\
\hline
\end{tabular}

(Sumber: Hasil olah data, 2015)
Penentuan kecenderungan variabel, maka selanjutnya mencari nilai rata-rata ideal (Mi) dengan rumus $\mathrm{Mi}=1 / 2\left(\mathrm{X}_{\max }+\right.$ Xmin), mencari standar deviasi ideal (SDi) dengan rumus $\mathrm{Sdi}=1 / 6\left(X_{\max }-X_{\min }\right)$. Berdasarkan acuan norma di atas, mean variabel kinerja guru adalah 52,5, dan standar deviasi ideal adalah 10,5. Dari perhitungan di atas dapat dikategorikan dalam 3 kelas yaitu baik, cukup dan kurang.

Berdasarkan perhitungan tersebut dapat dibuat tabel distribusi kecenderungan variabel kinerja guru sebagaimana disajikan pada Tabel 10.

Tabel 10. Kategorisasi Variabel Kinerja Guru

\begin{tabular}{ccccc}
\hline No & Skor & Frekuensi & Persentase & Kategori \\
\hline 1 & $\geq 63$ & 158 & 65,3 & Baik \\
2 & $42-62$ & 84 & 34,7 & Cukup \\
3 & $<42$ & 0 & 0 & Kurang \\
& & 242 & 100,0 & \\
\hline
\end{tabular}

(Sumber: Hasil olah data, 2015)

Tabel 10 menunjukkan bahwa kategorisasi kinerja guru sebagian besar pada kategori baik sebanyak 158 guru $(65,3 \%)$. Sisanya berada pada kategori cukup sebanyak 84 guru $(34,7 \%)$ dan pada kategori kurang tidak ada. Dengan demikian dapat disimpulkan bahwa kecenderungan kinerja guru di SMK Kabupaten Sleman pada kategori baik.

\section{Uji Hipotesis 1}

Hipotesis yang pertama dalam penelitian ini adalah: "Terdapat pengaruh yang positif dan signifikan antara kepemimpinan kepala sekolah terhadap kinerja guru". Untuk menguji hipotesis tersebut maka digunakan analisis regresi sederhana dan hasil pengolahan data dapat dijelaskan hal-hal sebagai berikut :

Angka R sebesar 0,465 menunjukkan bahwa terdapat korelasi/ hubungan antara variabel kinerja guru dengan variabel independennya yaitu kepemimpinan kepala sekolah dan dapat dikatagorikan "cukup".

Angka R Square atau Koefisien Determinasi adalah sebesar positif 0,216 (berasal dari $0,465 \times 0,465)$. Hal ini berati bahwa vari- 
asi dari variabel kinerja guru dapat dijelaskan oleh variabel kepemimpinan kepala sekolah sebesar $21,6,2 \%$, sedangkan sisanya sebesar $(100-21,6=78,4)$ atau $78,4 \%$ dijelaskan oleh faktor yang lain.

Persaaan regresi yang diperoleh adalah sebagai berikut:

$$
\mathrm{Y}=52.511+0.465 \mathrm{X} 1
$$

Koefisien regresi 0,465 menunjukkan bahwa setiap kepemimpinan kepala sekolah bertambah bertambah 1 poin, maka kinerja guru akan bertambah 0,465 poin. Sedangkan untuk menguji signifikansi konstanta dan setiap variabel independen dibangun Hapotesis sebagai berikut:

Ho $=$ Koefisien Regresi Tidak Signifikan

$\mathrm{Ha}=$ Koefisien Regresi Signifikan

Pengambilan keputusan berdasarkan probabilitas, yaitu dengan cara melihat kolom signifikansi (Sig.) dan diperoleh hasil sebagai berikut:

Jika Sig. > 0,05 maka Ho diterima, Ha ditolak Jika Sig. < 0,05 maka Ho ditolak , Ha diterima

Dari hasil pengolahan data diketahui nilai tingkat signifikansi sebesar 0,000, karena probabilitas/tingkat signifikansi ini lebih kecil daripada 0,05 (taraf signifikansi yang dipergunakan), dengan demikian Ho ditolak. Hal ini berarti bahwa model regresi ini dapat dipakai untuk memprediksi tingkat kinerja guru. Dengan kata lain: "Terdapat pengaruh yang positif dan signifikan antara kepemimpinan kepala sekolah terhadap kinerja guru".

\section{Uji Hipotesis 2}

Hipotesis yang kedua dalam penelitian ini adalah : "Terdapat pengaruh yang positif dan signifikan antara komitmen guru terhadap kinerja guru". Untuk menguji hipotesis tersebut maka digunakan analisis regresi sederhana dan hasil pengolahan data dapat dijelaskan hal-hal sebagai berikut

Angka R sebesar 0,397 menunjukkan bahwa terdapat korelasi/ hubungan antara variabel kinerja guru dengan variabel independennya yaitu komitmen guru dan dapat dikatagorikan "cukup".

Angka R Square atau Koefisien Determinasi adalah sebesar positif 0,158 (berasal dari $0,397 \times 0,397)$. Hal ini berati bahwa vari- asi dari variabel kinerja guru dapat dijelaskan oleh variabel komitmen guru sebesar $15,8 \%$, sedangkan sisanya sebesar (100-15,8 $=84,2$ ) atau $84,2 \%$ dijelaskan oleh faktor yang lain.

Persamaan regresi yang diperoleh adalah sebagai berikut:

$$
\mathrm{Y}=64.941+0.397 \mathrm{X} 1
$$

Koefisien regresi 0,317 menunjukkan bahwa setiap komitmen guru bertambah bertambah 1 poin, maka kinerja guru akan bertambah 0,317 poin. Sedangkan untuk menguji signifikansi konstanta dan setiap variabel independen dibangun Hapotesis sebagai berikut:

Ho $=$ Koefisien Regresi Tidak Signifikan

Ha $=$ Koefisien Regresi Signifikan

Pengambilan keputusan berdasarkan probabilitas, yaitu dengan cara melihat kolom signifikansi (Sig.) dan diperoleh hasil sebagai berikut:

Jika Sig. > 0,05 maka Ho diterima, Ha ditolak Jika Sig. < 0,05 maka Ho ditolak , Ha diterima

Dari hasil pengolahan data diketahui nilai tingkat signifikansi sebesar 0,000, karena probabilitas/tingkat signifikansi ini lebih kecil daripada 0,05 (taraf signifikansi yang dipergunakan), dengan demikian Ho ditolak. Hal ini berarti bahwa model regresi ini dapat dipakai untuk memprediksi tingkat kinerja guru. Dengan kata lain: “Terdapat pengaruh yang positif dan signifikan antara komitmen guru terhadap kinerja guru".

\section{Uji Hipotesis 3}

Hipotesis yang ketiga dalam penelitian ini adalah: "Terdapat pengaruh yang positif dan signifikan antara disiplin kerja guru terhadap kinerja guru". Untuk menguji hipotesis tersebut maka digunakan analisis regresi sederhana dan hasil pengolahan data dapat dijelaskan hal-hal sebagai berikut :

Angka R sebesar 0,465 menunjukkan bahwa terdapat korelasi/ hubungan antara variabel kinerja guru dengan variabel independennya yaitu disiplin kerja guru dan dapat dikatagorikan "cukup".

Angka R Square atau Koefisien Determinasi adalah sebesar positif 0,216 (berasal dari $0,465 \times 0,465)$. Hal ini berati bahwa variasi dari variabel kinerja guru dapat dijelas- 
kan oleh variabel disiplin kerja guru sebesar $21,6,2 \%$, sedangkan sisanya sebesar (100$21,6=78,4)$ atau $78,4 \%$ dijelaskan oleh faktor yang lain.

Persamaan regresi yang diperoleh adalah sebagai berikut:

$$
\mathrm{Y}=-6.718+0.317 \mathrm{X} 1
$$

Koefisien regresi 0,317 menunjukkan bahwa setiap disiplin kerja guru bertambah bertambah 1 poin, maka kinerja guru akan bertambah 0,317 poin. Sedangkan untuk menguji signifikansi konstanta dan setiap variabel independen dibangun Hapotesis sebagai berikut:

Ho $=$ Koefisien Regresi Tidak Signifikan

$\mathrm{Ha}=$ Koefisien Regresi Signifikan

Pengambilan keputusan berdasarkan probabilitas, yaitu dengan cara melihat kolom signifikansi (Sig.) dan diperoleh hasil sebagai berikut:

Jika Sig. > 0,05 maka Ho diterima, Ha ditolak Jika Sig. < 0,05 maka Ho ditolak , Ha diterima

Dari hasil pengolahan data diketahui nilai tingkat signifikansi sebesar 0,000, karena probabilitas/tingkat signifikansi ini lebih kecil daripada 0,05 (taraf signifikansi yang dipergunakan), dengan demikian Ho ditolak. Hal ini berarti bahwa model regresi ini dapat dipakai untuk memprediksi tingkat kinerja guru. Dengan kata lain: "Terdapat pengaruh yang positif dan signifikan antara disiplin kerja guru terhadap kinerja guru".

\section{Uji Hipotesis 4}

Hipotesis yang keempat dalam penelitian ini adalah: "Terdapat pengaruh yang positif dan signifikan antara budaya sekolah terhadap kinerja guru". Untuk menguji hipotesis tersebut maka digunakan analisis regresi sederhana dan hasil pengolahan data dapat dijelaskan hal-hal sebagai berikut:

Angka R sebesar 0,497 menunjukkan bahwa terdapat korelasi/hubungan antara variabel kinerja guru dengan variabel independennya yaitu budaya sekolah dan dapat dikatagorikan "cukup".

Angka R Square atau Koefisien Determinasi adalah sebesar positif 0,247 (berasal dari $0,497 \times 0,497$ ). Hal ini berati bahwa variasi dari variabel kinerja guru dapat dijelaskan oleh variabel budaya sekolah sebesar
$24,7 \%$, sedangkan sisanya sebesar (100$24,7=75,3$ ) atau $75,3 \%$ dijelaskan oleh faktor yang lain.

Persamaan regresi yang diperoleh adalah sebagai berikut:

$$
\mathrm{Y}=57.969+0.497 \mathrm{X} 1
$$

Koefisien regresi 0.497 menunjukkan bahwa setiap budaya sekolah bertambah bertambah 1 poin, maka kinerja guru akan bertambah 0,497 poin. Dari hasil pengolahan data diketahui nilai tingkat signifikansi sebesar 0,000, karena probabilitas/tingkat signifikansi ini lebih kecil daripada 0,05 (taraf signifikansi yang dipergunakan), dengan demikian Ho ditolak. Hal ini berarti bahwa model regresi ini dapat dipakai untuk memprediksi tingkat kinerja guru. Dengan kata lain: "Terdapat pengaruh yang positif dan signifikan antara budaya sekolah terhadap kinerja guru".

\section{Uji Hipotesis 5}

Hipotesis yang kelima dalam penelitian ini adalah: "Terdapat pengaruh yang positif dan signifikan antara kepemimpinan kepala sekolah, komitmen guru, disiplin kerja guru dan budaya sekolah secara simultan terhadap kinerja guru". Untuk menguji hipotesis tersebut maka digunakan analisis regresi berganda dan hasil pengolahan data dapat dijelaskan hal-hal sebagai berikut:

Angka R sebesar 0.715 menunjukkan bahwa terdapat korelasi/ hubungan antara variabel kinerja guru dengan semua variabel independennya yaitu kepemimpinan kepala sekolah, komitmen guru, disiplin kerja guru dan budaya sekolah secara simulatan (bersama-sama) dan dapat dikatagorikan "kuat".

Angka R Square atau Koefisien Determinasi adalah sebesar positif 0.512 (berasal dari $0,715 \times 0,715)$. Hal ini berati bahwa variasi dari variabel kinerja guru dapat dijelaskan oleh variabel kepemimpinan kepala, komitmen guru, disiplin kerja guru dan budaya sekolah secara simulatan (bersamasama) sebesar $51,2 \%$, sedangkan sisanya sebesar $(100-51,2=48,8)$ atau $48,8 \%$ dijelaskan oleh faktor yang lain. 
Persamaan regresi yang diperoleh adalah sebagai berikut:

\section{$\mathrm{Y}=-6.718+0.317 \quad \mathrm{X} 1+0.225 \quad \mathrm{X} 2 \quad+0.265$ $\mathrm{X} 3+0.323 \mathrm{X} 4$}

Persamaan tersebut menunjukkan bahwa nilai koefisien $\mathrm{X} 1$ sebesar 0.317 yang berarti kepemimpinan kepala sekolah (X1) meningkat 1 poin maka kinerja guru (Y) akan meningkat 0.317 poin dengan asumsi X2, X3, X4 tetap. Selanjutnya koefisien X2 sebesar 0.225 yang berarti apabila nilai komitmen guru (X2) meningkat 1 poin maka pertambahan nilai pada kinerja guru $(Y)$ akan meningkat 0.225 dengan asumsi $X 1$, X3, X4 tetap. Koefisien X3 sebesar 0.265 yang berarti apabila nilai disiplin kerja guru (X3) meningkat 1 poin maka pertambahan nilai pada kinerja guru $(\mathrm{Y})$ akan meningkat 0.265 dengan asumsi X1, X2, X4 tetap. Koefisien $\mathrm{X} 4$ sebesar 0.323 yang berarti apabila nilai budaya sekolah $(X 4)$ meningkat 1 poin maka pertambahan nilai pada kinerja guru (Y) akan meningkat 0.323 dengan asumsi $\mathrm{X} 1, \mathrm{X} 2, \mathrm{X} 3$ tetap.

Dari hasil pengolahan data diketahui nilai tingkat signifikansi sebesar 0,000, karena probabilitas/tingkat signifikansi ini lebih kecil daripada 0,05 (taraf signifikansi yang dipergunakan), dengan demikian Ho ditolak. Hal ini berarti bahwa model regresi ini dapat dipakai untuk memprediksi tingkat kinerja guru. Dengan kata lain: "Terdapat pengaruh yang positif dan signifikan antara kepemimpinan kepala sekolah, komitmen guru, disiplin kerja dan budaya sekolah secara simultan terhadap kinerja guru"

\section{Sumbangan Efektif dan Sumbangan Relatif}

Berdasarkan hasil analisis regresi ganda dapat diketahui besarnya Sumbangan Efektif (SE) dan Sumbangan Relatif (SR) setiap variabel bebas (kepemimpinan kepala sekolah, komitmen guru, disiplin kerja dan budaya sekolah) terhadap variabel terikat (kinerja guru).

Besarnya bobot sumbangan efektif untuk masing masing variabel bebas dan variabel terikat pada penelitian ini adalah sebagai berikut: Variabel kepemimpinan kepala sekolah mempunyai sumbangan efektif sebesar $14.8 \%$, komitmen guru mempu- nyai sumbangan efektif sebesar $8,9 \%$, disiplin kerja sebesar $11,4 \%$ dan budaya sekolah sebesar $16,1 \%$.

Selain diketahui besarnya sumbangan efektif untuk masing-masing variabel, hasil perhitungan juga menunjukkan besarnya sumbangan relatif untuk masing-masing variabel bebas. Variabel kepemimpinan kepala sekolah sebesar $28.9 \%$, komitmen guru sebesar 17,4\%, disiplin kerja sebesar 22,3\% dan budaya sekolah sebesar $31,4 \%$.

\section{Pembahasan}

Pengaruh Kepemimpinan Kepala Sekolah terhadap Kinerja Guru di SMK Kabupaten Sleman

Hasil penelitian ini menunjukkan bahwa kepemimpinan kepala sekolah berpengaruh positif dan signifikan terhadap kinerja guru SMK Kabupaten Sleman. Hasil penelitian ini sesuai dengan pendapat Mulyasa (2007, p. 140) bahwa salah satu faktor yang mempengaruhi kinerja guru adalah manajemen termasuk dalam hal ini kepemimpinan kepala sekolah. Hasil penelitian ini senada dengan hasil temuan dari Munfangati \& Widodo (2014, p. 230) yang menyatakan bahwa kinerja guru ditinjau dari nilai kompetensi yang dilakukan oleh Kepala Sekolah menunjukkan pencapaian sebesar $80,25 \%$ yang berarti baik.

Dengan demikian dapat diketahui bahwa semakin baik kepemimpinan kepala sekolah, maka semakin baik pula kinerja guru. Begitu sebaliknya semakin kurang baik kepemimpinan kepala sekolah dalam manajemen sekolah, maka semakin kurang baik pula kinerja guru di SMK Kabupaten Sleman.

Pengaruh Komitmen Guru terhadap Kinerja Guru di SMK Kabupaten Sleman

Hasil penelitian ini menunjukkan bahwa komitmen guru berpengaruh positif dan signifikan terhadap kinerja guru di SMK Kabupaten Sleman. Hasil penelitian ini sesuai dengan pendapat Hasibuan \& Moedjiono (2006, p. 40) bahwa salah satu faktor yang mempengaruhi kinerja guru dalam melaksanakan tugas mengajar yakni faktor perilaku guru. Faktor perilaku guru sangat menentukan proses keberhasilan 
belajar siswa diantaranya komitmen guru sebagai faktor intern dari perilaku guru. Semakin baik komitmen guru, maka semakin baik pula kinerja guru. Sebaliknya semakin kurang baik komitmen guru, maka semakin kurang baik pula kinerja guru di SMK Kabupaten Sleman.

Pengaruh Disiplin Kerja terhadap Kinerja Guru di SMK Kabupaten Sleman

Hasil penelitian ini menunjukan bahwa disiplin kerja berpengaruh secara positif terhadap kinerja guru di SMK Kabupaten Sleman. Disiplin kerja merupakan hal yang perlu dilakukan guru untuk mencapai kinerja yang lebih baik. Hal ini sesuai dengan pendapat Kunandar (2007, p. 60) menjelaskan bahwa dalam menjalankan tugasnya seorang guru harus memiliki beberapa kemampuan diantaranya disiplin dalam menjalankan tugas. Hal ini juga diperkuat dengan pendapat Mulyasa (2007, p. 136) bahwa kinerja merupakan hasil atau keluaran dari suatu proses. Apabila dalam proses menjalankan tugas guru melakukan kedisiplinan kerja yang baik, maka hasil kinerja juga akan menjadi baik.

Disiplin kerja guru merupakan salah satu tugas dari seorang guru. Kedisiplinan seorang guru dapat dilihat dari beberapa hal. Hal ini sebagaimana yang dikemukakan oleh Terry (1993) bahwa disiplin kerja seorang guru dapat dilihat dari kepatuhan guru terhadap peraturan yang berlaku di sekolah, termasuk tepat waktu ketika datang kesekolah dan tanggung jawab terhadap tugasnya sebagai pelajar, belajar sesuai dengan metode belajar yang telah disepakati bersama, pemeliharaan sarana dan perlengkapan belajar dengan baik.

Dengan demikian dapat diketahui bahwa semakin baik disiplin kerja guru, maka semakin baik pula kinerja guru. Sebaliknya, semakin kurang disiplin kerja guru maka semakin kurang pula kinerja guru di SMK Kabupaten Sleman.

Pengaruh Budaya Sekolah terhadap Kinerja Guru di SMK Kabupaten Sleman

Hasil penelitian ini membuktikan bahwa budaya sekolah berpengaruh positif terhadapkinerja guru di SMK Kabupaten sleman. Hal ini dapat dibuktikan dengan nilai signikansi sebesar 0,000 yang lebih kecil dari taraf signifikansi yang dipergunakan sebesar 0,05. Hasil penelitian ini dikuatkan dengan pendapat Mulyasa (2007, p. 140) bahwa salah satu faktor yang mempengaruhi produktivitas kerja adalah lingkungan dan suasana kerja.

Budaya sekolah sering disebut dengan iklim kerja yang menggambarkan suasana hubungan kerja antara sesama guru, antara guru dengan kepala sekolah, antara guru dengan tenaga kependidikan lainnya serta antardinas di lingkungannya merupakan wujud dari lingkungan yang kondusif. Menurut Hasanah (2008,p. 12), budaya sekolah dapat digambarkan melalui sikap saling mendukung (supportive), tingkat persahabatan (collegial), tingkat keintiman (intimate) serta kerja sama (cooperative). Kondisi yang terjadi atas keempat dimensi budaya sekolah tersebut berpotensi meningkatkan kinerja guru. Apabila budaya sekolah dapat dikembangkan maka efektivitas dan produktivitas sekolah akan meningkat dan peningkatan tersebut akan berdampak pada peningkatan kinerja.

Dengan demikian semakin baik budaya sekolah yang ada di lingkungan guru, maka semakin baik pula kinerja guru. Sebaliknya, semakin kurang baik budaya sekolah maka semakin kurang baik pula kinerja guru di SMK Kabupaten Sleman.

Pengaruh Kepemimpinan Kepala Sekolah, Komitmen Guru, Disiplin Kerja dan Budaya Sekolah secara Simultan terhadap Kinerja Guru di SMK Kabupaten Sleman

Berdasarkan hasil penelitian menunjukkan bahwa kepemimpinan kepala sekolah, komitmen guru, disiplin kerja guru dan budaya sekolah secara simultan berpengaruh signifikan terhadap kinerja guru di SMK Kabupaten Sleman. Hal ini dibuktikan dengan nilai nilai signifikansi sebesar 0,000 yang berarti kurang dari $0,05(0,000<0,05)$.

Hasil penelitian ini sesuai dengan pendapat Mulyasa (2007, p. 140) bahwa banyak faktor mempengaruhi kinerja diantaranya manajemen dalam hal ini kepemimpinan 
kepala sekolah, dan lingkungan termasuk budaya sekolah. Hasil penelitian ini juga sesuai dengan pendapat Hasibuan \& Moedjiono (2006, p.40) bahwa faktor yang mempengaruhi kinerja guru dalam melaksanakan tugas mengajar dyakni faktor lingkungan dan faktor perilaku guru. Faktor lingkungan sangat mempengaruhi tugas guru pada tahap sebelum pengajaran dan dalam menyusun suatu pelajaran. Yang termasuk kedalam faktor lingkungan diantaranya budaya sekolah. Sementara faktor perilaku guru sangat menentukan proses keberhasilan belajar siswa. Perilaku-perilaku yang harus dilaksanakan guru diantara dengan kedisiplinan kerja guru dan komitmen guru pada sekolah.

Dengan demikian dapat disimpulkan bahwa kepemimpinan sekolah, komitmen guru, disiplin kerja dan budaya sekolah berpangaruh secara simultan terhadap kinerja guru di SMK Kabupaten Sleman. Semakin baik kepemimpinan sekolah, komitmen guru, disiplin kerja dan budaya sekolah, maka semakin baik pula kinerja guru di SMK Kabupaten Sleman.

\section{Simpulan}

Berdasarkan hasil penelitian dan pembahasan maka dapat ditarik beberapa kesimpulan sebagai berikut: (1) terdapat pengaruh yang positif dan signifikan kepemimpinan kepala sekolah terhadap kinerja guru; (2) terdapat pengaruh yang positif dan signifikan komitmen guru terhadap kinerja guru; (3) terdapat pengaruh yang positif dan signifikan disiplin guru terhadap kinerja guru sebesar; (4) terdapat pengaruh yang positif dan signifikan budaya sekolah terhadap kinerja guru; (5) terdapat pengaruh yang positif dan signifikan kinerja kepemimpinan, komitmen guru, disiplin kerja guru dan budaya sekolah secara simultan terhadap kinerja guru.

Berdasarkan hasil analisis regresi ganda diketahui besarnya Sumbangan Efektif (SE) setiap variabel bebas terhadap variabel terikat. Besarnya bobot sumbangan efektif untuk setiap variabel bebas dan variabel terikat pada penelitian ini adalah sebagai beri- kut : variabel kepemimpinan kepala sekolah mempunyai sumbangan efektif sebesar $14,8 \%$, komitmen guru mempunyai sumbangan efektif sebesar $8,9 \%$, disiplin kerja mempunyai sumbangan efektif sebesar $11,4 \%$ dan budaya sekolah mempunyai sumbangan efektif sebesar $16,1 \%$.

Berdasarkan simpulan penelitian, ada beberapa saran yang dapat disampaikan yaitu sebagai berikut. Pertama, bagi pihak sekolah agar dapat menciptakan budaya sekolah yang kondusif yang dapat mendukung kinerja guru seperti menumbuhkan kerja sama, rasa persahabatan, dan saling mendukung dalam mencapai tujuan sekolah. Kedua, bagi guru agar meningkatkan komitmen dan disiplin kerja seperti tepat waktu ketika datang ke sekolah, patuh terhadap peraturan yang berlaku di sekolah dan loyal terhadap sekolah. Ketiga, bagi peneliti selanjutnya, hasil penelitian ini dapat menjadi bahan pertimbangan dan dapat melanjutkan penelitian dengan meneliti faktor-faktor lainnya yang mempengaruhi kinerja guru seperti faktor kompensasi dan faktor kreativitas guru.

\section{Daftar Pustaka}

Djohar. (2006). Guru, pendidikan dan pembinaanya (penerapannya dalam pendidikan dan undang-undang guru). Yogyakarta: Grafika Indah.

Hasanah, A. (2008). Produktivitas manajemen sekolah (studi kontribusi kepemimpinan kepala sekolah, budaya sekolah dan kinerja guru terhadap produktivitas sekolah menengah pertama di kota Bandung). Disertasi, tidak dipublikasikan. Universitas Pendidikan Indonesia Bandung.

Hasibuan, \& Moedjiono. (2006). Proses belajar mengajar. Bandung: Remaja Rosdakarya.

Kunandar. (2007). Guru profesional implementasi Kurikulum Tingkat Satuan Pendidikan (KTSP) dan sukses dalam sertifikasi guru. Jakarta: Raja Grafindo Persada.

Mulyasa, E. (2007). Manajemen berbasis 
sekolah konsep, strategi, dan implementasi. Bandung: Remaja Rosdakarya.

Munfangati, R., \& Widodo, P. (2014). Kinerja guru bahasa inggris bersrtifikat pendidik di Kota Yogyakarta. Jurnal Ling Tera, 1(2).

Presiden RI. Peraturan Pemerintah RI Nomor 74 Tahun 2008 tentang Guru (2008).

Sudriyah, \& Liana, L. (2015). Pengaruh motivasi kerja dan kompetensi profesional terhadap kinerja guru di moderasi oleh supervisi (studi kasus pada guru SMA Negeri wilayah timur di Kabupaten Pemalang). Jurnal Manajemen Dan Bisnis Indonesia, 4(1), 10-28.

Syukro, R. (2013, October). Kualitas pendidikan di Indonesia masih rendah. Berita Satu. Retrieved from http://www.beritasatu.com/pendidi kan/144143-kualitas-pendidikan-diindonesia-masih-rendah.html

Terry, G. R. (1993). Principles of management. Illinois: Learning System Compani. 